Abstracta Iranica Abstracta Iranica

Revue bibliographique pour le domaine irano-aryen

Volume 28 | 2007

Comptes rendus des publications de 2005

\title{
«Il colpo di stato di Timur a Balh nel 1370 ». Oriente Moderno, n.s. XXIV/2-3, 2005, pp. 309-325.
}

\section{Giorgio Rota}

\section{Q OpenEdition}

1 Journals

\section{Édition électronique}

URL : http://journals.openedition.org/abstractairanica/17342

DOI : 10.4000/abstractairanica. 17342

ISSN : 1961-960X

Éditeur :

CNRS (UMR 7528 Mondes iraniens et indiens), Éditions de l'IFRI

Édition imprimée

Date de publication : 15 mai 2007

ISSN : 0240-8910

Référence électronique

Giorgio Rota, « «II colpo di stato di Timur a Balh nel 1370 ». Oriente Moderno, n.s. XXIV/2-3, 2005, pp. 309-325. », Abstracta Iranica [En ligne], Volume 28 | 2007, document 151, mis en ligne le 18 septembre 2007, consulté le 25 septembre 2020. URL : http://journals.openedition.org/abstractairanica/17342 ; DOI : https://doi.org/10.4000/abstractairanica.17342

Ce document a été généré automatiquement le 25 septembre 2020.

Tous droits réservés 


\title{
« Il colpo di stato di Timur a Balh nel $1370 »$. Oriente Moderno, n.s. XXIV/2-3, 2005, pp. 309-325.
}

\author{
Giorgio Rota
}

1 This article deals with the first stage of Timur's conquering career. After obtaining the allegiance of a number of disaffected emirs, in 1370 Timur defeated and eventually put to death Amìr Hoseyn Qara'unas, then the ruler of the ulus Chaghatāy, effectively replacing him. These events are known only thanks to later sources: Bernardini employs in particular the Zafar-nāmes of Šāmī and Yazdī for his reconstruction of the facts. The campaign against Amī Hoseyn shows many features that will be recurrent themes in Timur's later career: the necessity to safeguard the law and the political order as a reason to wage war against a fellow Muslim ruler, whose weakness deprives him of his good right to rule; the presence of Muslim holy men (Seyyed Barake) on Timur's side; the presence of a Gengiskhanid figurehead (Soyūrghatmish Hुān in this case), with Timur acting ostensibly as a sort of atäbeg. However, the Author avers that, in the 1370s, the real reasons behind the political actions of Timur and the other emirs of the time were still closer to the traditional Turko-Mongol tribal politics and far from the "complex ideological structures" (p. 323) created by the later Persian historians working during Timur's heyday. The article also deals briefly with the issues of the identity of the Qara'unas, the change of the capital of the ulus from Balkh to Samarkand, and the nature of the political loyalty of the tribal chiefs. 
INDEX

Thèmes : 4.1. Histoire médiévale

\section{AUTEURS}

GIORGIO ROTA

Institut für Iranistik - Wien 